\title{
MICROMORPH TANDEM SOLAR CELLS GROWN AT HIGH RATE WITH IN-SITU INTERMEDIATE REFLECTOR IN INDUSTRIAL KAI PECVD REACTORS
}

\author{
Fanny Meillaud, Andrea Feltrin, Julien Bailat, Peter Buehlmann, Didier Dominé, Adrian Billet, \\ Grégory Bugnon and Christophe Ballif \\ Institute of Microtechnology, University of Neuchâtel \\ A.-L. Breguet 2, CH-2000 Neuchâtel, Switzerland \\ email: fanny.meillaud@unine.ch Tel: 41-32 7183319 Fax: 41-32 7183201
}

\begin{abstract}
We report on the latest results of tandem micromorph

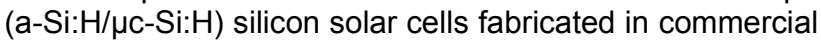
Oerlikon Solar KAI-S and KAI-M PECVD reactors. First developments of in-situ silicon oxide based intermediate reflector (SOIR) in KAI reactors are as well presented.

Under low depletion conditions (silane concentration $<10 \%$ ) our best micromorph solar cells achieve initial efficiencies up to $10.6 \%$ for a cell size $>1 \mathrm{~cm}^{2}$, with a deposition rate of $0.55 \mathrm{~nm} / \mathrm{s}$ for microcrystalline silicon and an ex-situ silicon oxide-based intermediate reflector (SOIR). Under high depletion conditions, the growth rate could be raised up to $1.2 \mathrm{~nm} / \mathrm{s}$, in a modified KAl-M reactor, and the highest initial efficiency reached so far is $9.7 \%$ with in-situ SOIR and top cell thickness of $\sim 230 \mathrm{~nm}$. Promising micromorph solar cells are thus produced under conditions that are highly favorable to low-cost fabrication of tandem modules at an industrial level.
\end{abstract}

\section{INTRODUCTION}

We showed in an earlier study [1] that very low flow of silane and hydrogen gases together with a high silane concentration SC (typically SC $\geq 50 \%$ ) were suitable for fabricating microcrystalline silicon ( $\mu \mathrm{c}-\mathrm{Si}: \mathrm{H})$ devices. Single-junction $\mu \mathrm{c}-\mathrm{Si}: \mathrm{H}$ solar cells with a conversion efficiency of $6 \% \quad\left(\mathrm{~V}_{\mathrm{oc}}=492 \mathrm{mV}, \quad \mathrm{FF}=73 \%\right.$, $J_{\mathrm{sc}}=17 \mathrm{~mA} / \mathrm{cm}^{2}$ ) were for the first time fabricated in a $\mathrm{KAI}-\mathrm{S}$ plasma reactor under high depletion conditions at a deposition rate of $1 \mathrm{~nm} / \mathrm{s}$. Such a high depletion regime is close to the former "closed chamber VHF" [2] as completely depleted silane plasma is maintained steadily during the intrinsic layer deposition. The minimum necessary silane gas flow is calculated based on the desired deposition rate, under the assumption of maximum gas consumption within the plasma [3, 4]. There are three major advantages for high depletion deposition: (a) the feedstock gas consumption is reduced by a factor close to ten, (b) the gain in growth rate leads to shorter fabrication times and (c) low RF power densities $\left(\sim 0.2 \mathrm{~W} / \mathrm{cm}^{2}\right)$ can be used.
Here, we focus on the development of tandem micromorph solar cells; the basic structure consists of a stack of glass/front contact/pin a-Si:H/pin $\mu \mathrm{c}-\mathrm{Si}: \mathrm{H} /$ back contact.

The thickness of the a-Si:H cell has to be kept as thin as possible to reduce the impact of the Staebler-Wronski effect [5]; its current thus generally limits the current of the whole tandem device. To overcome this issue, an intermediate reflector (IR) can be introduced between the bottom and the top cell in order to increase the current of the latter. For a layer to act as intermediate reflector, its refractive index $n$ must be lower than that of silicon (3.8 at $600 \mathrm{~nm}$ ) in order to produce a refractive index step that leads to light reflection at the interface. The IR must be sufficiently conductive, but as transparent as possible to minimize the current losses due to absorption of light outside the active layers.

\section{EXPERIMENTAL}

\section{Samples}

The single-junction $\mu \mathrm{c}-\mathrm{Si}: \mathrm{H}$ and tandem micromorph solar cells were deposited in pin configuration on AF-45 glass substrates with LPCVD (low-pressure chemical vapor deposition) $\mathrm{ZnO}$ (zinc oxide) as back and front contact [6]. A surface treatment, such as presented in [7] was applied to the front TCO. The cells were fabricated in Oerlikon KAI-S and KAI-M R\&D deposition systems at an excitation frequency of $40.68 \mathrm{MHz}$. All silicon layers were thus deposited with single-chamber processes. The solar cells are completely structured with areas of $0.25 \mathrm{~cm}^{2}$ or $1.2 \mathrm{~cm}^{2}$.

\section{Characterization techniques}

Electrical characteristics of the cells are obtained from (a) current-voltage measurements with a WACOM solar simulator in standard test conditions $\left(25^{\circ} \mathrm{C}\right.$, AM1.5g spectrum and $1000 \mathrm{~W} / \mathrm{m}^{2}$ ) as well as (b) external quantum efficiency measurements (EQE). The short-circuit current density $\mathrm{J}_{\mathrm{sc}}$ of the top and bottom solar cells is established by integrating, over the wavelength range from 350 to 
$1100 \mathrm{~nm}$, the product of EQE times the incoming photon flux (AM1.5g solar spectrum). The solar cells are lightsoaked under open-circuit conditions at a temperature of $50^{\circ} \mathrm{C}$, under an AM 1.5-like spectrum.

To assess the material's quality of the $\mu \mathrm{c}-\mathrm{Si}: \mathrm{H}$ i-layer incorporated in the single-junction devices, Fourier transform photocurrent spectroscopy (FTPS) was employed. This technique allows the measurement of the absorptance spectrum over several orders of magnitude. The setup consists of a FTIR spectrometer which output beam is focused on the solar cell, see details in [8].

The FTPS spectra were calibrated at $1.35 \mathrm{eV}$, by setting the absorption coefficient of the $\mu \mathrm{c}-\mathrm{Si}$ :H cell under test to the known value of crystalline silicon. The defectrelated absorption, which corresponds to the absorption coefficient value at $0.8 \mathrm{eV}$, is directly related to the defect density and, hence, to the i-layer material's quality, see e.g. $[8,9]$.

\section{RESULTS}

An ex-situ silicon oxide-based intermediate reflector was first used in our developments; it was deposited by very-high frequency PECVD at $110 \mathrm{MHz}, 200{ }^{\circ} \mathrm{C}$, with a power density of $0.01-0.1 \mathrm{~W} / \mathrm{cm}^{2}$ in a small area reactor. Its thickness is $95 \mathrm{~nm}$; further details for this SOIR are given in [10].

Fig. 1 shows the initial IV characteristics of the best micromorph tandem cell obtained under low depletion conditions (i.e. with a low silane concentration and a high gas consumption) with such SOIR (cell area: $1.2 \mathrm{~cm}^{2}$ ).

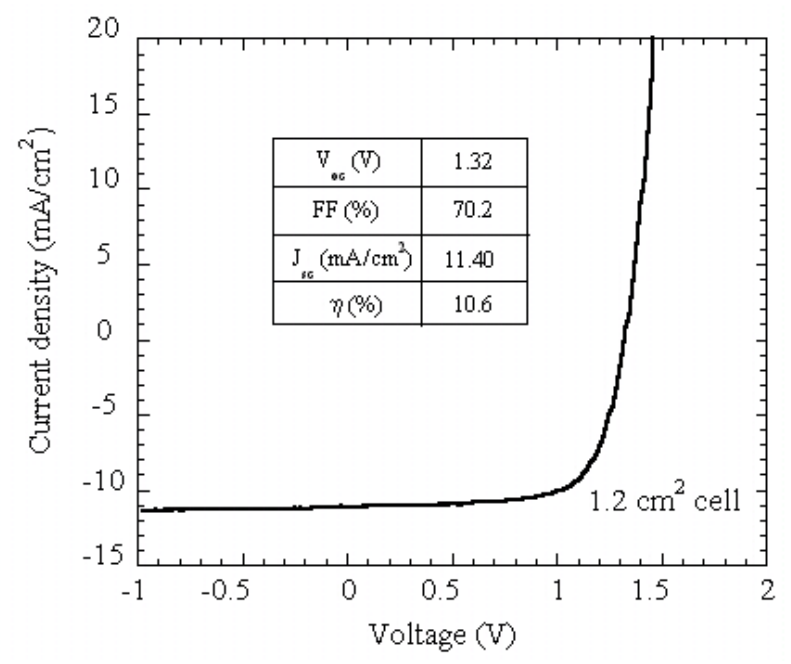

Fig. 1. Initial I-V characteristics of a-SiH/ $\mu \mathrm{c}-\mathrm{Si}: \mathrm{H}$ tandem solar cell deposited under low depletion conditions with exsitu SiO-based intermediate reflector (SOIR). The cell thicknesses are $250 \mathrm{~nm}$ for the top a-Si:H cell, $1.6 \mu \mathrm{m}$ for the bottom $\mu \mathrm{c}-\mathrm{Si}: \mathrm{H}$ cell. The short-circuit current density of the tandem is limited by the top cell.

The effect of ex-situ SOIR introduction on the external quantum efficiency (EQE) curves of the top and bottom cell of a micromorph tandem solar cell of an area of 0.25 $\mathrm{cm}^{2}$ is shown in Fig. 2:

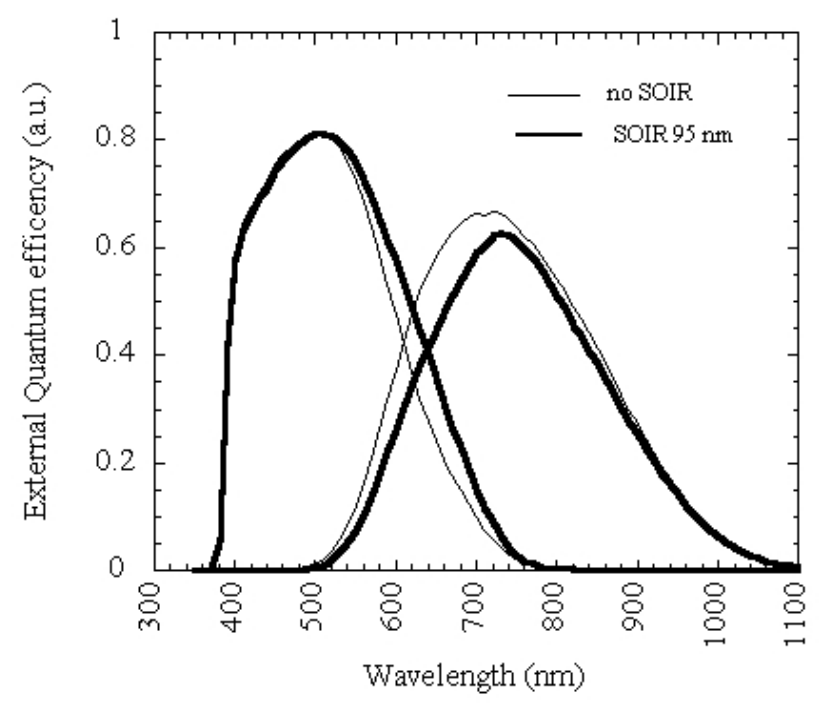

Fig. 2. External Quantum Efficiency measurement of micromorph tandem solar cell (area $0.25 \mathrm{~cm}^{2}$ ), deposited under low depletion conditions with and without $95 \mathrm{~nm}$ thick ex-situ silicon oxide based intermediate reflector. The thickness of the layers are $250 \mathrm{~nm}$ for the top cell and 1.6 $\mu \mathrm{m}$ for the bottom cell.

We observe that the quantum efficiency of the top cell is enhanced for wavelengths between $\sim 550$ and $800 \mathrm{~nm}$; this increase in EQE leads to an absolute gain in shortcircuit current density of $1.03 \mathrm{~mA} / \mathrm{cm}^{2}$ (from 10.77 to 11.80 $\mathrm{mA} / \mathrm{cm}^{2}$ ). But, the insertion of the SOIR also leads to a reduction of the bottom cell short-circuit current density from 12.71 to $11.07 \mathrm{~mA} / \mathrm{cm}^{2}$; however, this latter reduction can be avoided by increasing the $\mu \mathrm{c}-\mathrm{Si}: \mathrm{H}$ i-layer thickness.

For further development towards industrialization, effort was then concentrated towards (a) the fabrication of an insitu intermediate reflector in the KAl reactors and (b) the use of high depletion conditions to reduce the feedstock gas consumption, and hence, the production costs.

Two different regimes were established that permit to increase the growth rate to $0.9 \mathrm{~nm} / \mathrm{s}$ : (a) high depletionlow flow regime with a high silane concentration $(\sim 50 \%)$, (b) high power with a density of $0.45 \mathrm{~W} / \mathrm{cm}^{2}$. Singlejunction $\mu \mathrm{c}-\mathrm{Si}: \mathrm{H}$ solar cells were deposited under both regimes and an initial efficiency of $\sim 6.4 \%$ was obtained; $8.4 \%$ is achieved under standard conditions with a growth rate of $0.55 \mathrm{~nm} / \mathrm{s}$. As previously mentioned, the quality of the $\mu \mathrm{c}-\mathrm{Si}: \mathrm{H}$ material was checked with Fourier Transform Photocurrent Spectroscopy (FTPS): absorption spectra are presented in Fig. 3 for single-junction devices deposited in the three regimes (standard conditions at $0.55 \mathrm{~nm} / \mathrm{s}$, both regimes at $0.9 \mathrm{~nm} / \mathrm{s}$ ). The highest material's quality (i.e. the lowest $\alpha(0.8 \mathrm{eV})$ value) is obtained under standard conditions; the defect-related absorption is increased by a factor $\sim 8$ when using high depletion conditions at $0.9 \mathrm{~nm} / \mathrm{s}$, indicating that the plasma regime is not optimized yet. 


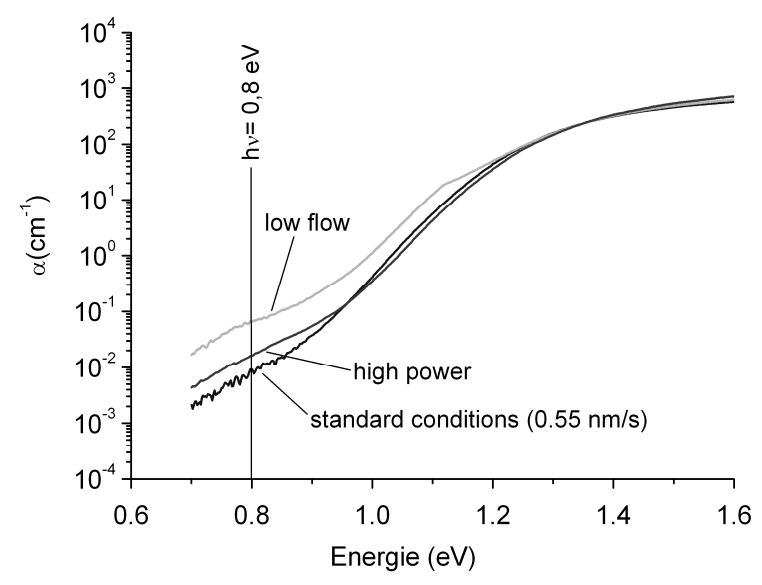

Fig. 3. Absorption spectra as a function of energy for single-junction $\mu \mathrm{c}-\mathrm{Si}: \mathrm{H}$ solar cells deposited under 3 regimes: (a) standard condition (SC $<10 \%$ ) at $0.55 \mathrm{~nm} / \mathrm{s}$, (b) low flow (SC 50\%) at $0.9 \mathrm{~nm} / \mathrm{s}$, (c) high power $\left(0.45 \mathrm{~W} / \mathrm{cm}^{2}\right)$ at $0.9 \mathrm{~nm} / \mathrm{s}$.

A micromorph tandem with an initial efficiency of $9.5 \%$ was achieved under high depletion conditions. After $3000 \mathrm{~h}$ of light-soaking, the stable efficiency is equal to $8.4 \%$ (- $11.6 \%$ relative). In order to further raise the growth rate without powder formation issues, the KAI-M reactor was modified. The growth rate was thus increased to $1.2 \mathrm{~nm} / \mathrm{s}$ and an initial efficiency of $7 \%$ was obtained for singlejunction $\mu \mathrm{c}-\mathrm{Si}: \mathrm{H}$ solar cell, see Fig. 4. Further optimization is under way to increase the efficiency.

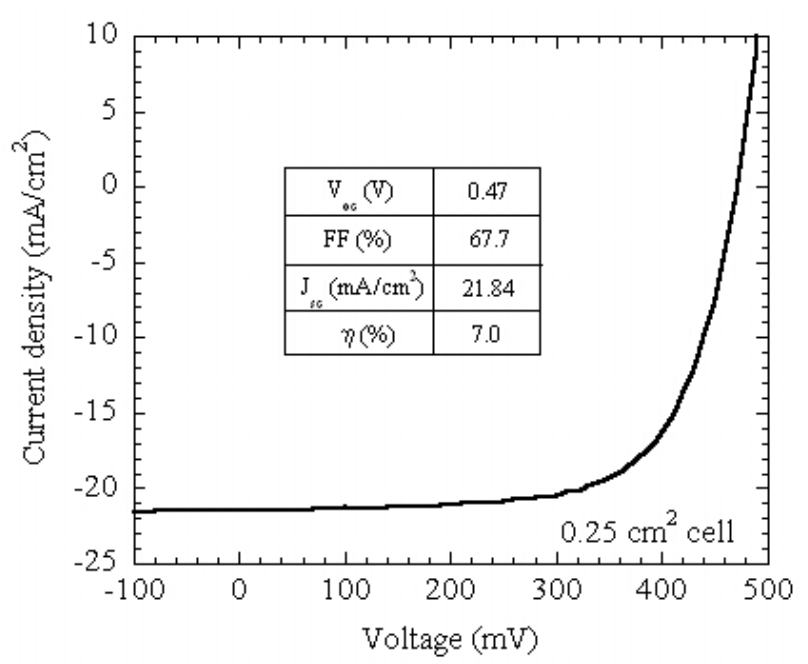

Fig. 4. Initial I-V characteristics of $\mu \mathrm{c}-\mathrm{Si}: \mathrm{H}$ single-junction solar cell deposited under high depletion conditions at 1.2 $\mathrm{nm} / \mathrm{s}$. The cell thickness is $1.2 \mu \mathrm{m}$

In order to get a complete process in the KAI reactors for the micromorph tandems, an in-situ SOIR has then been developed. Its reflectance and transmittance have been measured with a Perkin-Elmer spectrometer, type lambda 900, within a spectral range from 320 to $2000 \mathrm{~nm}$, and are presented in Fig. 5. The refractive index $n$ was estimated by fitting the transmittance and reflectance spectra with a dedicated software [11]: $\mathrm{n} \sim 2$ at $600 \mathrm{~nm}$.

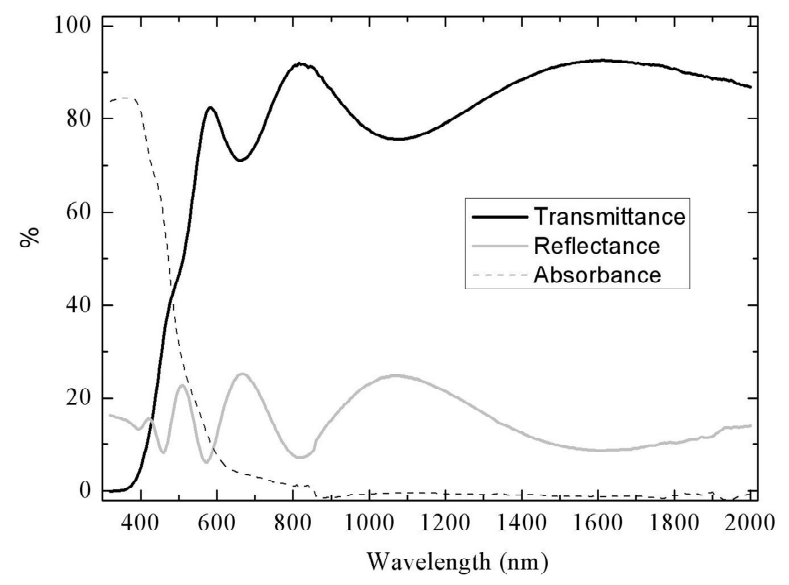

Fig. 5. Transmittance, reflectance and absorbance as a function of wavelength for the in-situ $\mathrm{SiO}$ based intermediate reflector deposited in the KAI-S system.

The best micromorph tandem deposited under high depletion conditions with in-situ SOIR is presented in Fig. 6; note that the a-Si:H top cell is only $~ 230 \mathrm{~nm}$ thick and the $\mu \mathrm{c}-\mathrm{Si}: \mathrm{H}$ is deposited at $1.2 \mathrm{~nm} / \mathrm{s}$. The short-circuit current density of the tandem is limited by the bottom cell.

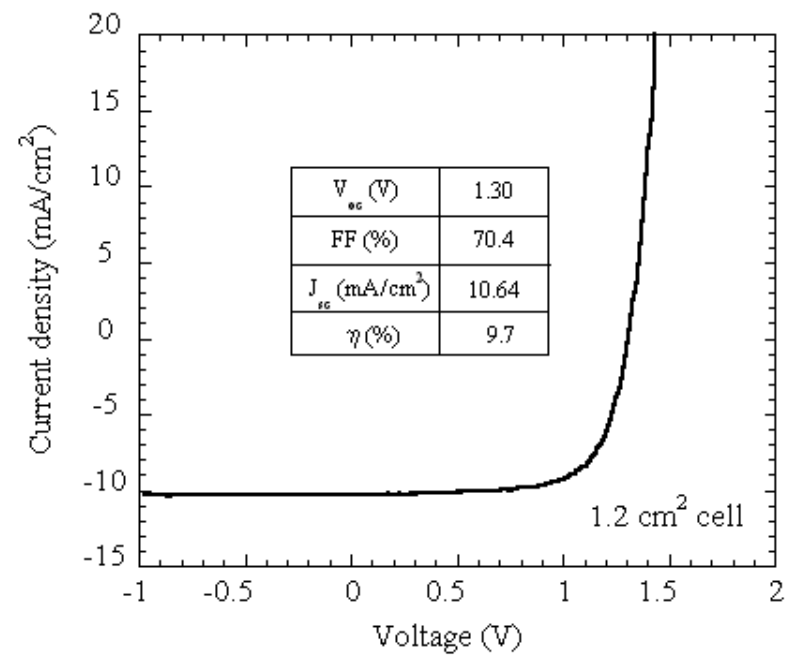

Fig. 6. Initial I-V characteristics of a-SiH/ $\mathrm{Mc}-\mathrm{Si}: \mathrm{H}$ tandem solar cell deposited under high depletion conditions with in-situ SiO-based intermediate reflector (SOIR). The cell thicknesses are $\sim 230 \mathrm{~nm}$ for the top a-Si:H cell, $1.6 \mu \mathrm{m}$ for the bottom (limiting) $\mu \mathrm{c}-\mathrm{Si}: \mathrm{H}$ cell. 


\section{CONCLUSIONS}

The major goal of thin-film photovoltaics is to further reduce the price per watt peak for modules. Such a goal can be achieved by (a) increasing the devices efficiency and (b) reducing the fabrication costs. We have demonstrated two major novelties in this contribution:

- the use of high depletion conditions for $\mu \mathrm{c}-\mathrm{Si}: \mathrm{H}$ material deposition and, hence, for tandem micromorph solar cells;

- $\quad$ the development of an efficient in-situ silicon-oxide based intermediate reactor in the KAl reactors.

Further investigations will now be focused on device optimization in the various plasma regimes, also including SOIR layers.

\section{ACKNOWLEDGMENTS}

The authors acknowledge financial support by the EUProject "ATHLET" under contract 019670 and the Swiss Federal Office of Energy under contract 101191.

\section{REFERENCES}

[1] L. Feitknecht et al, "Fast growth of microcrystalline silicon solar cells on LP-CVD ZnO in industrial KAI PECVD reactors", Proc of the $21^{\text {st }}$ EU PVSEC, Dresden, Germany, 2006, pp.1634-1636

[2] L. Feitknecht et al, "Plasma deposition of thin film silicon: kinetics monitored by optical emission spectroscopy", Solar Energy Mat \& Solar Cells 74, 2002, pp. $539-545$

[3] M.N. van den Donker, "Highly efficient microcrystalline silicon solar cells deposited from a pure $\mathrm{SiH}_{4}$ flow", Appl. Phys Letters 87, 2005, 263503

[4] B. Strahm et al., "Microcrystalline silicon deposited at high rate on large areas from pure silane with efficient gas utilization", Solar Energy Mat \& Solar Cells 91 (6), 2007, pp 495-502

[5] D. L. Staebler et al., "Reversible conductivity changes in discharge-produced amorphous Si", Appl. Phys. Lett. 31 (1), 1977, pp. 292-294

[6] S. Faÿ et al., "Rough ZnO layers by LP-CVD process and their effect in improving performances of amorphous and microcrystalline silicon solar cells", Solar Energy Mat \& Solar Cells 90 (18-19), 2006, pp. 2960-2967

[7] J. Bailat et al., "High-efficiency p-i-n microcrystalline and micromorph thin film silicon solar cells deposited on LPCVD ZnO coated glass substrates", Proc. of the 4th WCPEC Conference, Hawaii, USA, 2006, pp. 1533-1536
[8] M. Vanecek and A. Poruba, "Fourier-transform photocurrent spectroscopy of microcrystalline silicon for solar cells", Appl. Phys. Letter 80, 2002, pp. 719-721

[9] F. Meillaud et al., "Light-induced degradation of thin film amorphous and microcrystalline silicon solar cells", Proc. of the 31th IEEE PSEC, FL, USA, 2005, pp. 1412-1415

[10] P. Buehlmann et al., "In situ silicon oxide based intermediate reflector for thin-film silicon micromorph solar cells“, Appl. Phys. Lett. 91, 2007, 143505

[11] A. C. W. Biebericher et al., "Effects of Plasma Conditions on Density of Microcrystalline Silicon", Proc. of 19th EPSEC, Paris, France, 2004, pp. 1485-1488. 